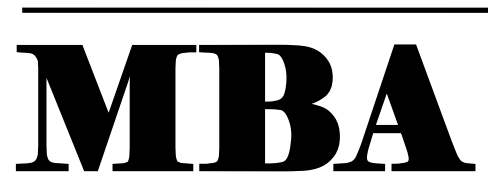

Vol. 4 , No. 2 , July 2021, page 427 - 435

ISSN 2614-1981 (Print)

ISSN 2615-0352 (Online)

Journal of Management and Business Aplication

\title{
STRATEGY OF EDUCATION QUALITY IMPROVEMENT ON SENIOR HIGH SCHOOL ARGOPURO PANTI
}

\author{
Syaehul Al-Hamzah ${ }^{1}$ \\ Muhammad Firdaus ${ }^{2}$ \\ Zainollah $^{3}$
}

Senior High School of Argopuro

Email : firdaus@stie-mandala.ac.id

\begin{abstract}
Quality of education is one of the central isue of national education among other isues such as equlization, relevance and educational management eficiencies. SMA Argopuro Panti is still faced with several obstacles that affect the quality of education, which regard to the background of students and their families, support of educational resources, teachers qualification, and low community participation. This research aims to obtain information about the policies underlying the school-based education quality improvement program, and how the school stakeholders understanding of the policy and to analyze information about alternative strategies for improving the quality of schoole-based education, regarding to the education program in SMA Argopuro Panti Jember. Informants in this study are founders of foundations, school committee members, and teacher, research subjects are relatively few and selected according to the research objects. In this study, collection uses snowball sampling techniques. Data analysis method uses SWOT analysis method. Based on the results of the analysis it is known that SMA Argopuro Panti is in a very favorable situation, it should able to compete because according to data analysis this school already has the strengthand opportuintyto improve its quality and dare to compete with other schools. The strategy applied in this condition is to support an aggressive growth policy growth oriented strategy.
\end{abstract}

Keywords : Strategy, Development, Quality of Education.

\section{INTRODUCTION}

Quality of education is one of the central isue of national education among other isues such as equlization, relevance and educational management eficiencies. To increase quality of education, we need to pay attention to the seven variables, those are (1) value of student learning evaluation, (2) class stay, drop out, and graduation, (3) educational facilities and infrastructure (schooling), (4)teacher qualification, (5)utilization of school facilities and infrastructure, (6) cost of education, and 
participation of parents and communities in the administration of education.

These seven variables are always a very important discussion in improving the quality of education.since one aspect that supports the development of educational institutioan depends on public trust in education units that is created through quality of education. To realize the implementation of quality education, the vision of national education in 2020 hasbeen established, namely: the realization of a high-quality, advanced, and independent Indonesian nation, society and people" (Depdiknas, 2000). Quality school is a school which overall can give satisfaction to the customers.

Base on the explaination above, the formulation of the problem is To improve the quality of SMA Argopuro Panti, it is necessary to thoroughly improve the management ofschool education without neglecting its internal potentials. According to Boast and Martin ( 2002; 143 ), from the point of view human investment, humans seems to have various potencies, and if those potencies are developed with high quality, $\mathrm{i}$ tis believed that humans will be able to solve various complex problems. The problem of the quality of education in the era of regional autonomy has recently been increasingly discussed, both national and local scale. In this contexts, $i$ tis important to note that the quality of education is not only limited to the qulity of student learning outcomes. In fact the quality of the learning outcomes is an illustration of the quality education motivated by many aspects that encourage the achievement of quality education, which is as raw inputs, instrumental inputs, environmental inputs, or as the implementation of quality process.

Other quality variables which influence basic education quality, including those held in high school units are school fee, number of students per class, teacher qualification, and the rasio of teacher and students.( Al Hamdani, 2003). This research aims to (1). To obtain information about the policies underlying the school-based education quality improvement program, and how the school stakeholders understanding of the policy, (2). To analyze information about alternative strategies for improving the quality of schoole-based education, regarding to the education program in SMA Argopuro Pnti Jember, (3). To analyze information about factors that support and hinder the success of the education quality, (4). To analyze information about the prospect of a quality improvement program for SMA Argopuro Panti Jember

The limitation of the problem in this study can be represented by the following questions:

1. What policies underlie the education quality improvement program in SMA Argopuro Panti, and how do stakeholders comprehension about the policies in SMA Argopuro Panti Jember?

2. What alternative strategies are more suitable applied to develop quality education in SMA Argopuro Panti Jember?

Those problems will be answered base on the analitical questios as below: What special programs can be applied to develop quality education in SMA Argopuro Panti Jember? How do resources support for implementing school-base education quality improvement program? What are the indicators of the success of the program? How to evaluate the success of the programs

3. What factors can support and inhibit the success of the education quality improvement program in SMA Argopuro Panti Jember? 
4. How is the prospect of the education quality improvement program in SMA Argopuro Panti Jember?

\section{RESEARCH METHODS}

The reasearch will be held in SMA Argopuro Panti Jember. It will be held on January until June 2018. In accordance with the nature of qualitative research, the subjects in tis study are determined by snow ball sampling, mean the research subjects are relatively few and are choosen according to the goal of study, however, the research sbjects can increase as needed. In this study, snow ball sampling technique is held if the data collection not only from one source, data collection is also taken from aother competence sources. For example, data collection is not only enough from the principal, but also from teachers, officials, students, comunity using education services. The technique of determining number of research subjects is called snow ball smapling ( Bogdan \& Biklen, 1982; Miles \& Hiberman, 1994 ; dan Nasution, 1992: 11, 33 )

\section{Data Collecting Method}

In accordance with the nature of qualitative research, researches are key instruments in data collecting. Therefore, researchers have flexible and adaptive role. Means, researchers can use their sensory tools to understand the fenomenon base on research focus. ( Lincoln dan Goba, 1985: 4; Bogdan dan Biklen, $1992 ; 28$ ). In this case, in the study, the researcher directly gets involve to collect datas base on the research focus, that $\mathrm{i}$ the improvement on quality education in SMA Argopuro Panti Jember. The teps of collecting datas in the research are: orientation, exploration, and checkmember step. The activity done in the first step is pre-survei to the research location to get description about problems to be researched. The second step is to collect data base on research focus. In this step, design activity and try out of alternative strategy model of the improvement of quality school base education. The third step is checkmember. It is aimed to verify datas or to check the validity of information collected through another data validation source.

Researcher is required to do ( 1 ). Intensive and long time interaction in the location. ( 2 ). Recording the event at location, making field note, and collects another documents. ( Such as : memo, notes, principal and teachers notes ); and ( 3 ). Next analytic reflection to the notes and documents collected in the field and reported in detailed description by making narrative skecthes and directly note from interview or by describing in more general forms.

\section{Interview}

The technique used in the research is non-structured interview as the form of this interview, researcher is unfully tied to the interview principle. The implementation can be done anytime and anywheresince $\mathrm{i}$ tis related to the phenomenon and research focus. Type of nterview used in this research is extensive and indepth interview (Patton, 1980).

\section{Observation.}

Kinds of reseaech used in qualitative research are non-interactive and interactive observation ( Bogdan \& Biklen, 1994 ). In non-interactive observatioan means indirect. However, in interactive observation means data collecting is done with the participants and by observation. In this observation researcher uses interactive participants and non participants observation dominantly (indirect and closed observation). Observation technique used in this research is by observing research object and situation. By this way, hoppingly researcher can observe phenomenons in research field to give and experience about research focus completely. 


\section{Documentations Study.}

Researcher also uses documentation study. Documents learned by the researcher deals with principal's school program information files, and other documents concerning with quality improvem,ent strategy through school-base education in SMA Argopuro Panti Jember.

\section{Literature Study.}

Beside using interview, observation and documentation study for data collectin, suitable information work research focus, researcher also uses literature study. Literation studied by the researcher is literature which deals with strategy of school-based quality improvement education.

\section{Data Analisis Method.}

Data Analysis Method used by researcher is an approach or SWOT analysis Model ( Freedy Rangkuti, 1997 ). Data analysis process used by researcher in this study is to find : (1). Strength, (2). Weakness, (3). Chance, (4). Threat, and (5). Data grouping (IFAS and EFAS).

\section{RESULT ANALYSIS}

The Result analysis of this study are:

Table 1. Strength Element

\begin{tabular}{llccc}
\hline \multicolumn{1}{c}{ No. } & \multicolumn{1}{c}{ SWOT Element } & Quality & Score & Total \\
\hline Strength & & & \\
\hline 1 & Strategic location in the middle of sub-distric & 0,2 & 5 & 1 \\
2 & $\begin{array}{l}\text { Proviede : Library, Science Laboratorium, } \\
\text { Place of worship, Bathroom, Computer }\end{array}$ & 0,1 & 5 & 0,5 \\
& $\begin{array}{l}\text { Laboratorium, Internet facilities. } \\
\text { Suitable teachers and staffs provided }\end{array}$ & 0,15 & 5 & 0,75 \\
4 & Sertified and Qualified teachers ( 65 \%) & 0,1 & 5 & 0,5 \\
5 & Teacher education is mostly undergraduate & 0,1 & 5 & 0,5 \\
& and some take S2 & & & 0,2 \\
6 & Graduation in 2012 / 2013 until 2017 / 2018 & 0,05 & 4 & 0,2 \\
7 & reach 100\% & 0,05 & 4 & 0,2 \\
8 & Various students input & 0,05 & 4 & 0,2 \\
9 & Amount of students ( 267 ) & 0,1 & 5 & 0,5 \\
& Means of transportation ( Mini Bus and & 0,1 & 5 & 0,5 \\
\hline & Carry ) & 1 & 38 & 4,9 \\
\hline
\end{tabular}

Table 2. Weakness Elements

\begin{tabular}{lllll}
\hline No. & \multicolumn{1}{c}{ SWOT Element } & Quality & Score & Total \\
\hline Weakness & & & \\
\hline 1 & Few classrooms unsuitable with National & 0,2 & 4 & 0,8 \\
& Education Standart & & & \\
2 & Few unrenovated classrooms & 0,2 & 3 & 0,6 \\
3 & Double teaching teacher & 0,1 & 2 & 0,2 \\
4 & Uncompetence librarian & 0,15 & 3 & 0,45 \\
5 & Unquilified administration staffs & 0,2 & 4 & 0,8 \\
6 & Uncompetence teachers in mechanic ( & 0,2 & 4 & 0,8 \\
$\quad$ Outomobile and Motor ) & & & \\
\hline & Total & 20 & 3,5 \\
\hline
\end{tabular}


Table 3. Chance Element

\begin{tabular}{lllll}
\hline No. & \multicolumn{1}{c}{ SWOT Element } & Quality & Score & Total \\
\hline Chance & & & \\
\hline \multicolumn{2}{l}{ Community"s opinion of good school } & 0,2 & 5 & 1 \\
1 & Professional teacher demands & 0,2 & 3 & 0,6 \\
2 & Supporting school committee & 0,2 & 4 & 0,8 \\
3 & Junior high school level, so many prospective & 0,15 & 4 & 0,6 \\
& students & & & \\
4 & Wide school location & 0,15 & 4 & 0,6 \\
5 & Many production unit arroung the school & 0,1 & 4 & 0,4 \\
\hline$\quad$ Total & 1 & 24 & 4 \\
\hline
\end{tabular}

Table 4 Threat Element

\begin{tabular}{|c|c|c|c|c|}
\hline No. & SWOT Element & Quality & Score & Total \\
\hline \multicolumn{5}{|c|}{ Threat } \\
\hline 1 & Other school improve their qulity & 0,3 & 4 & 1,4 \\
\hline 2 & School set in boarding school & 0,2 & 3 & 0,6 \\
\hline 3 & $\begin{array}{l}\text { Various economical students background ( } \\
\text { most of under middle class people ) }\end{array}$ & 0,2 & 4 & 0,8 \\
\hline 4 & $\begin{array}{l}\text { One of the student bases constrained by } \\
\text { transportation }\end{array}$ & 0,1 & 3 & 0,3 \\
\hline 5 & Unfair competition & 0,1 & 3 & 0,3 \\
\hline \multirow[t]{2}{*}{6} & $\begin{array}{l}\text { State regulation to minimalize students, } 20 \\
\text { students per classroom }\end{array}$ & 0,1 & 2 & 0,2 \\
\hline & Total & 1 & 15 & 3,6 \\
\hline
\end{tabular}

From the analysis result above, it can be formulated in IFAS table (Internal (External Strategic Analysis Summary). Strategic Analysis Sumamary ) and EFAS

Table 5. Metrix Ifas and Efas

\begin{tabular}{cccc}
\hline \multicolumn{2}{c}{ IFAS } & \multicolumn{2}{c}{ EFAS } \\
\hline Category & Sub-total & category & Sub-total \\
Strength ( S ) & 4,9 & Chance ( O ) & 4 \\
Weakness ( W ) & 3,5 & Threat ( T ) & 3,6 \\
Total ( S - W ) & 1,4 & Total ( O - T ) & 0,4 \\
\hline
\end{tabular}


From the score it is known that strategy used is by using the strength possessed by school to improve the quality and competition positition.

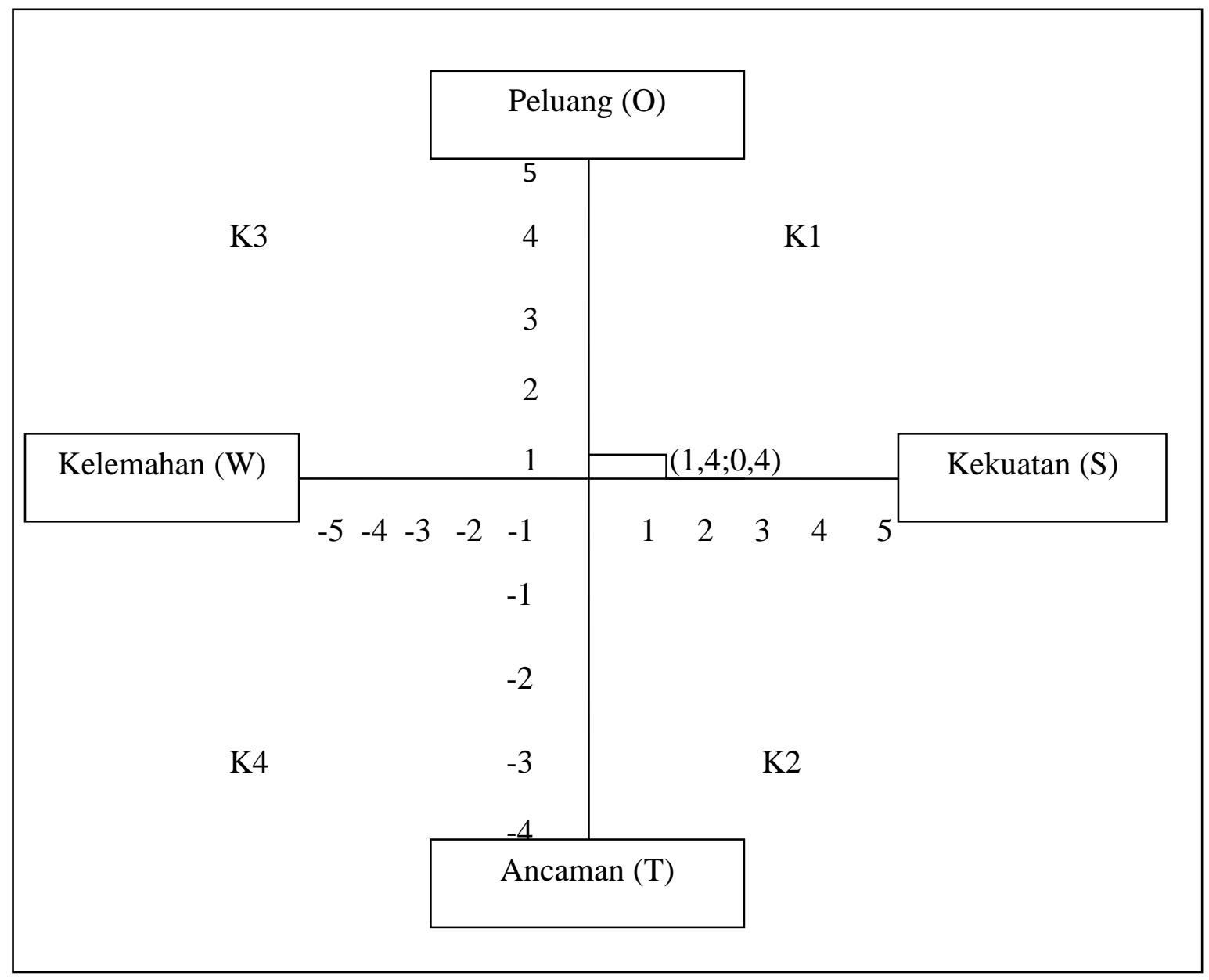

Figure. 1. Strategi SWOT

\section{INTERPRETATION}

From the picture of SWOT analysis diagram above it can be known that SMA Argopuro Panti Jember is located in a favourable stiuation that be able to compete as the school data analysis has strength and chance to improve the quality that can compete with other institution. Strtegy applied in this condition is support growth oriented strategy.

The power possessed by this school, strategic position is in the middle of subdistric is the factor that support the improvement of school as it is easily accessed, possessing complete facilities. It can be identified that this school has high competeiveness through other school. This school is also supported by qualified teachers, and sertified teacher about $65 \%$, teachers' education background mostly undergraduated and some take S2 degree. Students in this school have high graduated annually, and from facilities aspect this school has a student transportation bus, and one viewer in each classroom supports the learning process more interactive.

Chance possessed is the internal teachers and staffs that make good image to community and also think that this school is good that can make internal teachers and staffs optimistically think to get more students, they orient to be professional, the 
involvement of shcool committee improve the school anthusiastically. Yunior high school graduation level can bet he chance to get more students. Land for school development is provided, many production unit are as means to improve students quality. Power owned by SMA Argopuro Panti can optimalize the strength to improve the quality of education, the strategy is also presented by Moch. Syaifulloh, dkk ( 2012). In his research, he stated that in improving the quality of education at school, must be held with various activities, such as upgrading program, seminar, or workshop. Through those activities, it is introduced learning innovations, since innovations are a need.

Materials improvement for study, startegy and learning method strategy, learning media improvement, scoring system, evaluation, and assessment have become main menu in education world, however, empirical experience seems not significantly make a change in improving quqlity education at school. So, wnhat must to do is commitment of continous qualty improvement and process of continous pross improvement. Commitment on quality is started dedicated statement on mission and vision together, continous quality improvement base on two elements. Firstly, study the process, tools, and correct competence. Secondly, apply new skill small achieveable project. Continous improvement process can be fulfilled base on Action cycle. This cycle is a never ending improvement cycle, and obtained to all intstution phase, especially for education institution.

According to Nur'aeni (2013), to improve qulity education, strategy used is, first, improve human resources, modernization of institutional management. Second, consolidation to find good practise and experience that can be taken from either discussion, totality focus or broad focus through workshops, or seminar on improving the quality of learning.

Ijudin (2014) stated in his researh that strategies used to improve the qulity education are, first, education of character values through formal education seem to be more effective, such as, informal education in family, and in community. Second, cultural education and character of the nation through formal education at school must be integrated on all subjects, selfdevelopment though extra-curricular activities, and habitual school cultur. Institution and teachers must integrate the values improved on cultural education and character of the nation in the curriculum, syllabus, lesson plan (RPP) provided, applied self-development program and train, familiarize righteousness values in school's scocial order. Third, character education through school education will face a hard challange. Internal challange can be, educational orientation that prioritizes success in cognitive aspects, educational practice that base on rasionalism philosophy that gives the important role to reasoning ability, unsupported teacher's character and abilities, and also unsupported school culutre. Hence, external challanges are: globalization impact, community improvement, and the influence of the development of information and communication technology, that can change social life order.

According to Yusia (2016), in her reseach stated that strategies applied to improve eduacation quality are : (1). Take the advantage of accreditation achievements A, National Standart School (SSN), good students input, numbers of students who achieve non-academic field and $100 \%$ graduation to gain cmmunity's opinion that this school is excellent and good quality. (2). Utilize many teachers who have S1 and S2 degree to fulfill professional teachers demand. (3). Utilize the library to increase 
student's reading intrest and add the collection of books by cooporating with others. (4). Utilize internet facilities to find and add learning materials to make learning process more interesting. There is a similar strategy applied in SMA Argopuro Panti, that is optimalizing the power owned by a certain instituion, but the difference in this study is the power owned by SMA Argopuro Panti, first, the strategic location is in the central of sub-distirct, so it can accessed easily by students. Second, means of transportation is a plus value of an institution, so students who do not have their own means of transportastion can take it as $i$ tis provided by school, and parents choose this transportation for their children as a safe enjoyable reason to school. Third, optimalize sertified teachers work, sertified teachers are as the indikator that the teacher is qualified, this is as the power of the school, because it can be parent's consideration to choose a certain education institution.

Septiani, dkk (2017) in her researh that strategy apllied to improve quality education is, School-base Managenement Implementation (MBS), the study focuses on strategic location which lied on the alternative for northern way, is as a challenge for students' safety as traffic activities. This condition can be challenge for students' safety to enter school area. Base on the former research, there were relevancy in basic differences on strategy applied in an institution are: first, optimalize the sertified teachers' work. Second, optimalize administration staff's and librarian's work and improve the competencies for librarian, admintration staff in library and in administration. Third, give an additional competence in outo mobile mechanism and motor mechanism. Fourth, recruitmen profeesional expert in the mechanical field ( auto mobile mechanic + motor mechanic ) in accordance between the institution and production units (workshop) in Panti. Fifth, give a special service to students who have the competence on either academic and non academic field. Sixth, students means of transportastion.

\section{CONCLUSION}

Based on the result of research done, and the former analysis chapter, it can be concluded that quality education and quality improvement strategy which is appropriate applied are:

Education quality plicies of SMA Argopuro Panti are:

1. Produce graduates who are faithful and devoted to Allah SWT and berakhlakul karimah ( relegius personality)

2. Produce graduates who are masterized on science and technology as demand

3. Improve the quality of students through exercise, thought, taste, and sports to have competetiveness in facing global challenges.

4. Produce graduates who are in accordance with the demands of the needs based on the potensial of Indonesia's natural resources.

5. Improve the effeiciency of education menagement carried out through the application of school-base management and renewal of planned, directed and sustainable management of education.

6. Harmonizing school education quality policy with state policy about the quality of education contained in governmanet regulation No. 195, 2005 about National Education Standart

7. Set-up and fostergood coorporation with educational institutions. Education at school and especially concerned in the central ando outside of sub-district Panti.

8. Coordinate and harmonize all resources inside and outside the school, to achieve the stated PMBS goals. 
To realize an education quality policy, then the education quality strategy is prepared as belows:

1. Optimalize the sertified teachers' work in Indonesian, English, Math, Chemist, Biology, Sociology, Economy, and Geography,

2. Optimalize the librarian and administration staffs' work,

3. Provide additional competencies in outomobile and motor mechanics to students,

4. Expert recruitment in mechanics in accordance with other institutions and production unit (workshop) in sub-distric, Panti,

5. Optimalize extra curricular activities in Scout, and Paskibraka,

6. Provide special services to students who have special skill,

7. Provide additional competencies in entrepreneurship through extracurricular: mushroom cultivication, fishery, farm, and Agriculture,

8. Optimalize means of transportation for students

9. Empower library facilities optimally to increase student interest in reading and add to the collection of books in collaboration with others.
10. Provide spesial activity with boarding school models for student XII grade.

\section{REFERENCES}

Abu-Dhou, I. (2003). School-Based Management (Manajemen Berbasis Sekolah). Buku Serial Dasar-dasar Perencanaan Pendidikan UNESCO. Terjemahan oleh Aini, Sapto, dan Jauhari. Pengantar oleh Prof. Dr. H. A. Malik Fadjar, M.Sc. Jakarta: Logos Wacana Ilmu.

Combs, P. H. (1968). The World Education Crisis: A System Analysis. New York: Oxford University Press.

Fadjar, A. M. (1998). Visi Pembaruan Pendidikan Islam. Jakarta: LP3NI.

Field, J. C. (1994). Total Quality for School. Ontario: Prentice Hall Canada Inc.

Miles, M. B. dan Huberman, A. M. (1994). Qualitative Data Analysis (Second Ed.). London: Sage Publication.

Rangkuti, Freddy, (1997) Analisis SWOT : Teknik membedah kasus bisnis, cara penghitungan bobot, rating, dan OCAI. Jakarta : Gramedia

Yusia, (2016). Strategi peningkatan mutu sekolah dengan menggunakan analisa SWOT 